\title{
FREEDOM OF CONTRACT: COMPARISON BETWEEN PROVISIONS OF THE CISG (ARTICLE 6) AND COUNTERPART PROVISIONS OF THE PECL*
}

\author{
Ulrich Schroeter ${ }^{* *}$
}

\section{CONTENTS}

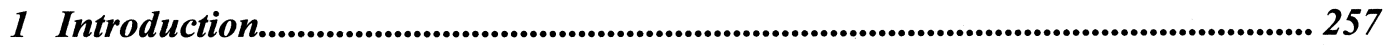

2 Freedom of Contract under the CISG and PECL ................................................. 258

3 Restrictions to the Parties' Freedom of Contract Under the CISG and PECL.... 259

4 Restrictions to the Parties' Freedom of Contract in Cases Where CISG Applies Solely Because of the Parties' Choice ('opting in')..................................... 265

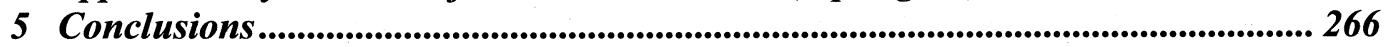

\section{INTRODUCTION}

Article 6 CISG lays down the general rule that the Convention applies to international contracts of sale of goods, subject to a contrary agreement by the parties. Its counterparts in Arts. 1:102 and 1:103 PECL likewise address the principle of freedom of contract and its limitations, but differ from Art. 6 CISG in a number of respects. These differences primarily flow from the different legal nature of the two sets of rules - while the CISG in its Contracting States forms part of the substantive law that the courts have to apply (lex fori), the applicability of the PECL in general requires an agreement of the parties that submits their contract to the Principles (1:101 PECL) - and reflect the different approaches that the drafters of the CISG and the PECL have adopted with respect to the limitations to the freedom of contract, in particular those limitations arising from so-called mandatory rules of law. As a consequence, the use of Arts. 1:102 and 1:103 PECL as an aid to interpret Art. 6 CISG is subject to a number of important caveats discussed below.

This comparative analysis has been printed with the kind permission of the Institute of International Commercial Law of the Pace University School of Law as part of a comparative analysis of the CISG with the Principles of European Contract Law (PECL). This article will soon be available at $<$ http://cisgw3.law.pace.edu $>$.

** The author studied law at the University of Freiburg (Germany) and the University of Lausanne (Switzerland), and graduated from the University of Freiburg in 1998. Since 2000 he is a member of the Graduiertenkolleg 'Europäisches Privat- und Wirtschaftsrecht' at the HumboldtUniversity in Berlin (Germany), and since 2002 he serves as a post-graduate judicial trainee (Rechtsreferendar) at the Kammergericht (Court of Appeals) in Berlin. 


\section{FREEDOM OF CONTRACT UNDER THE CISG AND THE PECL}

The principle of freedom of contract, one of the basic principles underlying the international law of contracts in general, has been recognised by both the drafters of the CISG and of the PECL. The wording of Art. 6 CISG and Art. 1:102(2) PECL is in fact quite similar, and the prominent position of both provisions among the first articles in the Convention and the PECL illustrate the important role of the parties' autonomy. ${ }^{1}$

Articles 1:101(2), (3) and 1:103(1) PECL additionally address a somewhat related issue: the choice of the PECL as the law applicable to the contract. This issue concerns the applicability of the respective set of rules. The question of applicability may also arise under the CISG, albeit in different form: while the PECL are only applicable where the parties have chosen the Principles and the law otherwise applicable allows such a choice, the Convention is applicable as a matter of law whenever the prerequisites of Art. 1(1)(a), (b) CISG are fulfilled (and none of the exceptions in Arts. 2-5 CISG applies). ${ }^{2}$ The parties' choice of the CISG as the law applicable to their contract will therefore lead to the Convention's applicability under Art. 1(1)(b) CISG if the rules of private international law of the forum (being situated in a Contracting State) accept the principle of party autonomy, ${ }^{3}$ as it will under the private international law rules of most non-

$1 C f$. Bonell, M.J., 'Article 6', in Commentary on International Sales Law, no. 1.2 (Bianca, C.M. \& Bonell, M.J. eds., 1987): 'the prevailing view in UNCITRAL was in favour of the widest possible recognition of the parties' autonomy'; Siehr, K., 'Artikel 6', in Kommentar zum UN-Kaufrecht, No. 1 (Heinrich Honsell ed., 1997): the drafters of the CISG wanted to grant the parties a wide discretion in drafting their contract; see also Landgericht [Regional Court] Stendal, Germany, 12 October 2000, Internationales Handelsrecht 2001, at p. 32, where the court stated that Art. 6 CISG affirms the principle of party autonomy; for English translation of the text of this case, go to $<$ http://cisgw3.law.pace.edu/cisg/text/draft/001012case.html $>$.

2 For agreements to apply the Convention to transactions that fall outside the scope of Arts. 1-5 CISG, please see fn 4 .

3 . In practice, contractual choice of law clauses usually do not point to the Convention as such, but rather to the law of a certain State: If this State happens to be a Contracting State, the CISG will generally apply, as it forms part of the legal system of each Contracting State: see relevant case law, e.g.:

Bundesgerichtshof, [Federal Supreme Court, Germany] 23 July 1997, Neue Juristische Wochenschrift (1997) 3309, at p. 3310 [Case presentation in English available at

$<$ http://cisgw3.law.pace.edu/cases/970723g1.html $>$ ]; Oberster Gerichtshof, [Supreme Court, Austria], 22 October 2001, $1 \mathrm{Ob} 77 / 01$ [English translation available at

$<$ http://cisgw3.law.pace.edu/cases/011022a3.html>]; U.S. Federal District Court [New York], 26 March 2002 (St. Paul Insurance Company et al. v. Neuromed Medical Systems \& Support et al.), available on-line at $<\mathrm{http}: / /$ cisgw3.law.pace.edu/cases/020326u1.html $>$, where the court stated: 'The parties concede that pursuant to German law, the U.N. Convention on Contracts for the International Sale of Goods ("CISG") governs this transaction because (1) both the U.S. and Germany are Contracting States to that Convention, and (2) neither party chose, by express 
Contracting States. ${ }^{4}$ On the contrary, under Art. 1(1)(a) CISG, which covers cases where both parties have their places of business in different Contracting States (statistically by far the most important group of CISG contracts), any agreement of the parties or any other indication that the parties were even aware of the CISG's applicability is unnecessary ${ }^{5}$ - the Convention is, unlike the PECL, not merely a model law or Restatement of principles of contract law, but is applicable by law whenever the parties have not excluded its application (so-called 'opting out'). ${ }^{6}$

\section{Restrictions to the PARTIES' FREEdom of CONTRACT UNDER the CISG AND THE PECL}

More important differences exist with respect to the restrictions to which the CISG and the PECL submit the parties' freedom to exclude the respective set of rules

provision in the contract, to opt-out of the application of the CISG. The CISG aims to bring uniformity to international business transactions, using simple, non-nation specific language. To that end, it is comprised of rules applicable to the conclusion of contracts of sale of international goods. In its application regard is to be paid to comity and interpretations grounded in its underlying principles rather than in specific national conventions. See Art. 7(1), (2) CISG. Germany has been a Contracting State since 1991, and the CISG is an integral part of German law. Where parties, as here, designate a choice of law clause in their contract - selecting the law of a Contracting State without expressly excluding application of the CISG - German courts uphold application of the Convention as the law of the designated Contracting State. To hold otherwise would undermine the objectives of the Convention which Germany has agreed to uphold.' [citations omitted]

See also Ferrari, F., 'Artikel 6', in Kommentar zum Einheitlichen UN-Kaufrecht, No. 22 (Schlechtriem. P., ed., 3rd edn., 2000, with numerous references to international case law). Whether an 'isolated' choice of the CISG as the law applicable to the contract is valid and effective depends on the relevant conflict of law rule. Under the EC Convention of the Law Applicable to Contractual Obligations (Rome, 19 June 1980), this question is heavily disputed; cf. Siehr, K., 'Der internationale Anwendungsbereich des UN-Kaufrechts', 52 Rabels Zeitschrift für ausländisches und internationales Privatrecht (1988), at p. 612. See also Honnold, J.O., Uniform Law for International Sales under the 1980 United Nations Convention, No. 83 (3rd ed. 1999) who argues that full effect should be given to the parties' agreement to apply the Convention.

4 In States that have not ratified the Convention, the courts do not apply Art. 1(1)(b) CISG which, for lack of ratification, does not form part of the lex fori - but look to the national private international law rules. Cf. Morse, C.J.G., 'Conflict of Laws', in Benjamin's Sale of Goods, No. 25-025 (Guest, A.G., ed., 5th edn., 1997): 'It is therefore possible that a United Kingdom court may have to apply the Vienna Convention on the International Sale of Goods 1980, if the law applicable under the Rome Convention is found to be the law of a country which is a party to that Convention and that country would regard that Convention as applicable'. A choice of law clause will thus for all practical purposes yield identical results in Contracting States and nonContracting States.

de la Convencion de Viena, at p. 100 (Díez-Picazo, L., \& de León, P., eds., 1998); Ferrari, please see fn 3, No. 23; Piltz, B., Internationales Kaufrecht (1993), § 2 No. 108.

6 Ferrari, F., please see fn 3, no. 6; Magnus, U., 'Artikel 6', in von Staudingers, J., Kommentar zum Bürgerlichen Gesetzbuch mit C.J.G. Einführungsgesetz und Nebengesetzen, Wiener UNKaufrecht (CISG) (1999), No. 2. 
and modify the effect of their provisions. The Principles list three different categories of restrictions:

\subsection{GOOD FAITH AND FAIR DEALING}

According to Art. 1:102(1) PECL, the parties may determine the contents of their contract 'subject to the requirements of good faith and fair dealing'. Article 6 CISG does not contain a similar limitation to the freedom of contract. During the 1980 Vienna Diplomatic Conference, a proposal to add a second sentence to the wording of Art. 6 CISG stating that 'the obligations of good faith, diligence and reasonable care prescribed by this Convention may not be excluded by agreement' was rejected by a substantial majority. ${ }^{7}$

However, the principles of good faith and fair dealing may under certain circumstances also affect the content of CISG contracts. This may, on one hand, be the case where, according to the applicable national law, the validity of the contract or of any of its provisions (Art. 4(a)) CISG is subject to these principles. On the other hand, a number of commentators hold that Art. 7 CISG similarly requires the principles of good faith and fair dealing to be taken into account when determining the parties' rights and obligations under the contract, although this interpretation is subject to dispute. ${ }^{8}$

\subsection{MANDATORY RULES ESTABLISHED BY THE CISG/PECL THEMSELVES}

Secondly, Art. 1:102(1) and (2) PECL subjects the freedom of contract to the mandatory rules established by these Principles. Such rules of mandatory nature are contained in Arts. 4:118 PECL (limiting the exclusion or restriction of remedies for fraud, threats, excessive benefit or unfair advantage-taking, mistake

7 The Canadian proposal (A/CONF.97/C.1/L.10) as orally amended aimed at revising the draft of Art. 6 CISG to read as follows: 'The parties may exclude the application of this Convention or, subject to Art. 11 [became Art. 12 CISG], derogate from or vary the effect of any of its provisions. However, except where the parties have wholly excluded this Convention, the obligations of good faith, diligence and reasonable care prescribed by this Convention may not be excluded by agreement'. See U.N. Official Records (1981), at p. 86. Article 6 CSIG thus goes beyond the language of the Uniform Commercial Code $\S 1-102(3)$ which contains a restriction similar to the one mentioned above, $c f$. Farnsworth, E.A., 'Review of Standard Forms or Terms Under the Vienna Convention', 21 Cornell International Law Journal (1988) 439, at p. 441 note 8 [available on-line at $<$ http://www.cisg.law.pace.edu/cisg/biblio/farns $1 . h t m l>]$.

8 To the present writer, this interpretation of Art. 7 CISG seems doubtful. In this respect, see Felemegas, J., 'Editorial remarks on CISG Article 7', available on-line at $<$ http://www.cisg.law.pace.edu/cisg/text/e-text-07.html $>$. 
and incorrect information), 6:105 (dealing with the determination of the price and other contractual terms where it is to be determined by one party and that party's determination is grossly unreasonable) and 8:109 (declaring the exclusion or restriction of remedies for non-performance inadmissible when it would be contrary to good faith and fair dealing to invoke that restriction).

Article 6 CISG, on the contrary, names Art. 12 CISG as the one provision in the Convention that the parties may not derogate from, thus making Art. 12 the only mandatory rule in the CISG. ${ }^{9}$ Although some commentators have suggested that other provisions in the Convention (such as Arts. $4,{ }^{10} 7,{ }^{11} 28,{ }^{12} 89$ et seq. ${ }^{13}$ ) are also mandatory despite not being mentioned in Art. 6 CSIG, it is submitted that none of these articles restrict the parties' freedom of contract. ${ }^{14}$

9 Herber, R., 'Artikel 6', in Commentary on the UN Convention on the International Sale of Goods, No. 5 (Schlechtriem. P., ed., 1998); Heuzé, V., La vente internationale de marchandises (1992), No. 97; Honnold, please see fn 3, No. 74; Rudolph, H., Kaufrecht der Export- und Importverträge (1996), Art. 6 No. 1; Siehr, please see fn 1, No. 11.

10 Bonell, please see fn 1, No. 3.4.

11 Bonell, please see fn 1, 'Article 7', No. 3.3, who argues that 'any legislation has to be interpreted in accordance with the criteria specifically laid down in it or generally adopted within the legal system from which it emanates'. This approach accepts that the parties to an international sales contract are free to choose between the application of CISG and the application of a particular domestic law, but insists that once the contracting parties have accepted that their contract of sale is to be governed by the CISG, the provisions of the Convention must be applied in accordance with Art. 7 CISG, which provides the Convention's in-built interpretation rules.

12 Bonell, please see fn 1, No. 3.4; Ferrari, please see fn 3, No. 9; Magnus, please see fn 6, No. 28; Reinhart, G., UN-Kaufrecht (1991), Art. 28 No. 3.

13 Ferrari, please see fn 9.

14 Derogating from Art. 4 CISG would make little sense, as it would lead to the Convention being applicable to questions of contractual validity and transfer of property on which it contains no rules (Ferrari, please see fn 3, No. 11; Rudolph, please see fn 9, No. 1). An agreement by the parties on principles of interpretation other than those in Article 7 CISG is allowed under the parties' right to modify the Convention's provisions according to their own preferences (Ferrari, please see fn 3, no. 10; Magnus, please see fn 6, No. 55). Professor Bonell's argument against allowing parties to do away with Art. 7 CISG via the autonomy given to them in Art. 6 CISG (please see fn 11) seems, in the last analysis, unconvincing: Art. 6 CISG expressly states that the parties may not only accept or exclude the Convention's application in toto, but also derogate from or vary the effect of any provision they consider undesirable despite the fact that the drafters of the CISG included it. Whenever such a contractual modification of one of the CISG's articles occurs, a court judgment or arbitral award applying the Convention to that particular contract cannot insofar be regarded as a persuasive precedent (which is to be taken into account by other courts under Art. 7 CISG) as it does not deal with the interpretation of the CISG's original rules, but merely with a modified version of the Convention. A scenario involving a contractual derogation from Art. 7 CISG does in this respect not differ from cases where modifications of other provisions are at stake: Should the parties - which, it is submitted, will rarely occur in practice - choose to have, e.g., the CISG 'as interpreted by German courts' or 'as construed according to the principles of English law' govern their contract, this constitutes an admissible use of their party autonomy according to Art. 6 CISG, but deprives any judgment or arbitral award dealing with this contract of sale of its future persuasive value under Art. 7(1) CISG. 
Thus the principle of contractual freedom in the Convention goes beyond its counterpart provision in the PECL. The absence of limitations similar to the mandatory PECL rules mentioned above should not come as a surprise as the Convention's scope is restricted to transactions and issues which, within the various domestic laws, are traditionally governed by provisions of a nonmandatory character, ${ }^{15}$ while the PECL additionally deal, inter alia, with questions of contractual validity and are also intended to apply to contracts involving consumers. $^{16}$

\subsection{MANDATORY RULES OF NATIONAL, SUPRANATIONAL AND INTERNATIONAL} $\boldsymbol{L A W}$

The third and last category of restrictions to the freedom of contract under the PECL covers the mandatory rules of national, supranational and international law (Art. 1:103(1), (2) PECL). According to Art. 1:103(1) PECL, national mandatory rules are applicable if the law otherwise applicable does not allow their exclusion by way of choice by the parties, and Art. 1:103(2) PECL requires courts and arbitrators to give effect to mandatory rules of national, supranational and international law which are applicable irrespective of the law governing the contract (mandatory rules carried by a strong public policy, so-called 'directly

Under Art. 28 CISG, a court is not required to grant specific performance if, under its 'own law', it would not do so. If the parties, by explicitly derogating from Art. 28 CISG in their contract, have agreed on one or both parties' right to specific performance, it can be assumed that the court would carry out the agreement of the parties (Kastely, A.H., 'The Right to Require Performance in International Sales: Towards an International Interpretation of the Vienna Convention', 63 Washington

Law Review (1988), at p. 642 [available on-line at

$<$ http://www.cisg.law.pace.edu/cisg/biblio/kastely1.html $>$ ]; Lando, O., 'Article 28', in Commentary on International Sales Law, No. 3.1 (Bianca, C.M. \& Bonell. M.J., eds., 1987)).

While the parties cannot modify the Contracting States' obligations under public international law arising from Arts. 89 CISG et seq., they may modify the Final Provisions' effect on their own contract, e.g., by agreeing on the Convention's applicability although the prerequisites of Art. 100 CISG are not met: Arts. 89 CISG et seq. are thus subject to the parties' freedom of contract as far as they deal with the Convention's sphere of application (Siehr, K., please see fn 1, No. $11)$.

15 Bonell, please see fn 1, No. 2.1; Calvo Caravaca, please see fn 5, at p. 93; Honnold, please see fn 3, No. 74.

$16 C f$. Lando, O. \& Beale, H., Introduction, in Principles of European Contract Law, Parts I and II (2000), at p. xxv. Purchases by consumers are excluded from the Convention's scope by virtue of Art. 2(a) CISG, although the CISG will apply if the seller neither knew nor ought to have known that the goods were bought for personal, family or household use - a type of situation that may become more common as more consumers purchase goods over the internet. Sales by consumers are, on the contrary, not excluded from the Convention's scope (Herber, please see fn 9, Article 2 No. 11; Magnus, please see fn 6, 'Artikel 2' No. 18). 
applicable rules' or règles d'application immédiate). The Principles thus demand that, when applying the law, a distinction is drawn between rules of mandatory and non-mandatory nature, between mandatory rules of national, supranational and international law and between 'ordinary' mandatory rules and règles d'application immédiate - decisions that can be difficult to make and will accordingly be often unforeseeable for the parties. ${ }^{17}$

Under the CISG, the situation is different: as far as matters governed by the Convention - either by way of an express provision or by way of its general principles identified in accordance with Art. 7(2) CISG - are concerned, no mandatory rule of national, supranational and international law may be applied. ${ }^{18}$ This follows from the fact that the Contracting States have accepted an obligation under public international law to apply the Convention instead of any other legal rule wherever the Convention provides uniform rules. ${ }^{19}$ Thus, provisions outside the CISG are - irrespective of their mandatory or non-mandatory nature superseded if their subject matter is already covered by the Convention.

As not all matters which are potentially relevant to international sales contracts are governed by the Convention, mandatory rules of national, supranational and international law are to be given effect whenever a matter is outside the CISG's scope. In this respect, difficult questions may arise under Art. 4(a) CISG, which stipulates that 'except as otherwise expressly provided in this Convention, it is not concerned with [...] the validity of the contract or of any of its provisions or of any usage'. This provision seems to leave ample room for the application of mandatory rules that deal with questions of validity. However, Art. 4(a) CISG sets out an important - and often overlooked - additional condition by requiring courts and arbitrators to establish in advance that the Convention is not itself concerned with the validity question regulated by the otherwise applicable mandatory provision. Accordingly, not all rules of national, supranational or international law

17 The vagueness of the term 'mandatory' was also criticised during the discussions within UNCITRAL; Honnold, please see fn 3, No. 79.

18 Enderlein, F. \& Maskow, D., International Sales Law (1992), Art. 6 no. 3.1 [available on-line at $<$ http://www.cisg.law.pace.edu/cisg/biblio/enderlein.html $>$ ]; Herber, please see fn 9, No. 24; Lorenz, M., 'Artikel 6', in International Einheitliches Kaufrecht: Praktiker-Kommentar und Vertragsgestaltung zum CISG, No. 20 (Witz, W. Salger, H-C. \& Lorenz, M., eds., 2000); Magnus, please see fn 6, No. 55; Reinhart, please see fn 12, Art. 6 No. 8; Rudolph, please see fn 9, No. 6.

19 This has been aptly described by Professor Honnold as 'the commitment that Contracting States make to each other: We will apply these uniform rules in place of our own domestic law on the assumption that you will do the same' (Honnold, please see fn 3, No. 103.2); see also Calvo Caravaca, fn 5, at p. 100. 
prescribing that a contract or one of its clauses is void or invalid are applicable to CISG contracts by virtue of Art. 4(a) CISG. ${ }^{20}$

Under Art. 4(a) CISG, it has thus to be taken into account not only whether the national provision has an effect on the validity of certain clauses in a CISG contract, but also why the national law imposes the sanction of invalidity. As a result, for instance, the doctrine on vices cachés under French law is inapplicable to CISG contracts although it addresses the validity of contractual clauses limiting the seller's liability as it does so by defining rules on the lack of conformity of the goods on which the Convention itself contains an exhaustive regulation. ${ }^{21}$ The same applies to the common law validity doctrine of consideration, which conflicts with the express language of Art. 29(1) CISG ${ }^{22}$ Both examples are indications of one of the Convention's main contributions to the modern law for international sales which has been described by Ernst Rabel as 'avoiding the awesome relics of the dead past that populate in amazing multitude' the national sales laws. ${ }^{23}$ Other national mandatory rules remain applicable under Art. 4(a) CISG, but only under the condition that the CISG's provisions and fundamental principles are taken into account when they are applied to a CISG contract: If, for example, the national law declares clauses in general business terms invalid if they are incompatible with the

20 Ferrari, please see fn 3, 'Artikel 4' No. 13; Herber, please see fn 9, No. 13; Honnold, please see fn 3, No. 65; Magnus, please see fn 6, 'Artikel 4' No. 18. For an interesting discussion on how drafters of standard terms should deal with the interaction between the national rules on validity and the Convention, please see Farnsworth fn 7, at pp. 443ff. See also Bundesgerichtshof, [Federal Supreme Court, Germany], 31 October 2001, Neue Juristische Wochenschrift (2002) 370 , at p. 371 where the court ruled on the CISG's requirements for the inclusion of standard terms and conditions into contracts of sale. [Case presentation, including English translation and commentary available at $<\mathrm{http}: / /$ cisgw3.law.pace.edu/cases/011031g1.html $>$ ]. The court held that Art. 8(2) CISG requires the user of standard terms to transmit the respective text to the other party or make it available in another way, and justified its interpretation inter alia with the assumption that 'a control of the content of standard terms and conditions under national law (Art. 4(a)) CISG is not always guaranteed'. While the decision is likely to receive some criticism for imposing excessively strict requirements for the inclusion of standard terms, it indicates a tendency to limit the scope of the validity exception in Art. 4(a) CISG in favour of the Convention's own rules.

21 Audit, B., La vente internationale de marchandises: Convention des Nations-Unies du 11 avril 1980 (1990), at pp. 115ff.; Heuzé, please see fn 9, No. 100.

22 Audit, please see fn 21, at pp. 32, 74; Heuzé, please see fn 9, No. 201; Honnold, please see fn 3 , No. 204.1ff; see also Schlechtriem, P., 'Artikel 29', in Kommentar zum Einheitlichen UNKaufrecht, no. 3 (Schlechtriem. P., ed., 3rd edn., 2000).

23 Rabel, E., 'The Hague Conference on the Unification of Sales Law', 1 American Journal of Comparative Law (1952), at p. 61. See also Honnold, please see fn 3, No. 30: 'One may delight in legal antiques and in the patina of ingenious circumlocutions that have had to substitute for fundamental reform but these aesthetics may not be appreciated by a modern merchant and, more especially, by his trading partner from a different legal tradition'. 
essential principles of the rules from which the parties are derogating, ${ }^{24}$ the relevant essential principles are those of the Convention. ${ }^{25}$

\section{Restrictions to the PARTIES' FreEdom of ContraCt in CASES WhERE THE CISG APPLIES SOLELY BECAUSE OF THE PARTIES' CHOICE ('OPTING IN')}

The limited relevance of mandatory rules of national, supranational or international law for CISG contracts that has been outlined above (see 3c, above), however only extends to international contracts of sale to which the Convention applies by virtue of Arts. 1-5 CISG. The legal situation is different where the parties have chosen the Convention's rules when the CISG would otherwise not be applicable: Nothing in the CISG precludes such a contractual agreement leading to the applicability of the Convention (so-called 'opting in'). ${ }^{26}$ It can be useful when two parties from non-Contracting States fail to reach agreement on which national law should govern their contract, ${ }^{27}$ where 'string contracts' or 'chain transactions' are at stake which involve parties from CISG Contracting States and from non-Contracting States alike and which may therefore be only partially subject to the Convention, if no explicit choice in favour of the CISG is made, ${ }^{28}$ and may be inserted into

24 See for example $\S 307(2) \mathrm{Nr} .1$ of the German Civil Code.

25 Herber, please see fn 9, No. 28; Koch, R., Wider den formularmäßigen Ausschluss des UNKaufrechts, Neue Juristische Wochenschrift (2000), at p. 910; Lorenz, please see fn 18, No. 14; Magnus, please see fn 6, 'Artikel 4' No. 26; Piltz, please see fn 5, § 2 No. 140; Schmidt, H., in $A G B$-Gesetz, Anh. § 2 No. 12 (Ulmer, P., Brandner, H.E. \& Hensen, H-D., eds., 9th edn., 2001); Lindacher, W.F., in $A G B-G e s e t z$, Anh. $§ 2$ No. 75 (Wolf, M., Horn, N. \& Lindacher, W.F. eds., 4th edn., 1999). In Oberster Gerichtshof, [Supreme Court, Austria], 7 September 2000, Recht der Wirtschaft (2000), No. 9 the court held that the parties can derogate from Art. 49(1) CISG and restrict the buyer's rights under the condition that these clauses are valid under the applicable domestic (here: German) law according to Art. 4 CISG. However, even if the changes are valid according to the rules of the applicable domestic law, such rules must not contradict the fundamental principles (Grundwertungen) of the CISG. The Court stated that one of the CISG's fundamental principles is the right for the buyer to avoid the contract, which the buyer must have as ultima ratio where the seller after an additional period of time still has not delivered the goods or where the goods in spite of the seller's remedies are still essentially useless. This right to avoid the contract can only be validly restricted if the buyer at least retains the right to damages. [Case presentation available in English at: $<\mathrm{http}: / / \mathrm{cisgw} 3$.law.pace.edu/cases/000907a3.html $>$ ].

26 Audit, please see fn 21, at p. 41; Enderlein \& Maskow, please see fn 18, Art. 6 No. 3.2; Herber, please see fn 9, No. 31; Honnold, please see fn 3, No. 79ff; Lorenz, please see fn 21; Reinhart, please see fn 12, Art. 6 No. 9. For the discussions during the 1980 Vienna Diplomatic Conference, see U.N. Official Records (1981), at p. 252ff.

27 Calvo Caravaca, please see fn 5, at p. 100; Reinhart, please see fn 12, Art. 6 No. 89.

28 Audit, please see fn 21, at p. 41; Honnold, please see fn 3, No. 82; Lorenz, please see fn 18, No. 21; Piltz, B., Entscheidungen des BGH zum CISG, Internationales Handelsrecht-Beilage zu der Zeitschrift Transportrecht (1999), at p. 14. 
distribution contracts or other frame contracts applying to sales to international and domestic customers alike. ${ }^{29}$

Thus, whenever the CISG applies solely because of the parties' choice and without the requirements of Arts. 1-5 CISG having been met, mandatory rules of national, supranational or international law remain relevant and need to be applied by courts and arbitrators, ${ }^{30}$ as in these cases the CISG resembles the PECL and other Restatements. ${ }^{31}$ Accordingly, in such a setting, Art. 1:103 PECL may be used as an aid in interpreting or supplementing the CISG.

\section{CONCLUSIONS}

While the parties' freedom of contract plays a very important role within both the CISG and the PECL, the two instruments are marked by a number of important differences that concern the legal restrictions to the parties' autonomy. The legal nature of the CISG as an international convention has allowed its drafters to go beyond the limits laid down in Arts. 1:102 and 1:103 PECL. ${ }^{32}$ The specific scope of the freedom of contract under Art. 6 CISG therefore makes it difficult to use the PECL as an aid to the interpretation of the said CISG provision.

29 Audit, please see fn 21, at p. 40; Heuzé, please see fn 9, No. 125.

30 Audit, please see fn 21, at p. 41; Bonell, please see fn 1, No. 3.5.1; Calvo Caravaca, please see fn 5, at p. 101; Enderlein \& Maskow, please see fn 18, Art. 6 No. 3.2; Herber, please see fn 9, No. 31; Heuzé, please see fn 9, No. 127; Honnold, please see fn 3, No. 84; Reinhart, please see fn 12, Art. 6 No. 9; $c f$. Lorenz, please see fn 18, No. 21; Siehr, please see fn 1, No. 15.

31 Honnold, please see fn 3, No. 84; Magnus, please see fn 6, Nos. 62, 65; Rudolph, please see fn 9, No. 9.

32 See also Rudolph fn 9, No. 1: Article 6 CISG grants the parties more freedom than most national laws do; Farnsworth, please see fn 7, at p. 441 fn 8 (for the U.C.C.). 